RESIDENT

\& FELLOW

SECTION

Section Editor

Mitchell S.V. Elkind,

MD, MS

Xinli $\mathrm{Du}, \mathrm{MD}, \mathrm{PhD}$

Yang Tang, MD, PhD

Christopher M. Inglese, MD

Address correspondence and reprint requests to Dr. Xinli Du, Department of Neurology, Box 800394, Charlottesville, VA 22901

Xd5m@virginia.edu

\title{
Teaching NeuroImages: \\ Neonatal intracerebral hemorrhage associated with aortic coarctation
}

\section{Figure $1 \quad$ Noncontrast head CT}

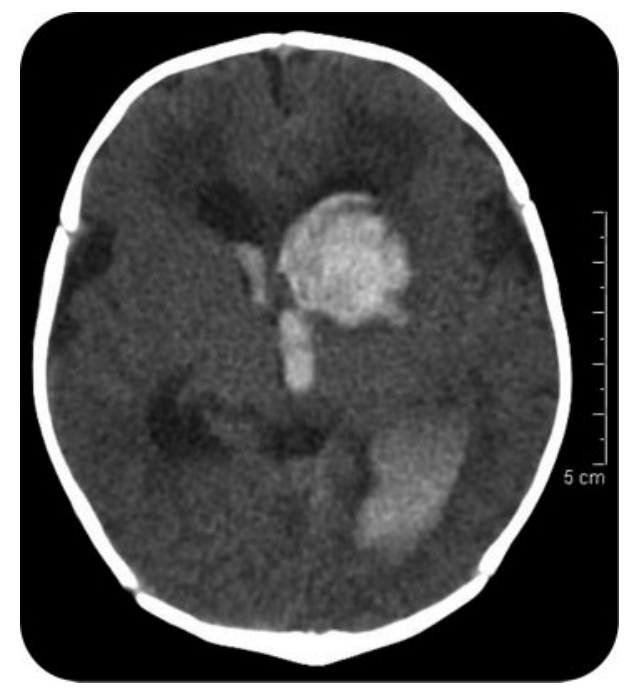

Left basal ganglia hemorrhage with extension to the lateral and third ventricles and hydrocephalus were seen.
A previously healthy, vaginally delivered, term neonate developed spontaneous intracerebral hemorrhage (figure 1) at 3 weeks of age. Echocardiogram showed postductal aortic coarctation. His blood pressure in the right arm was 167/ $108 \mathrm{~mm} \mathrm{Hg}$ (normal $79 \pm 8 / 49 \pm 8$ ), and 111/78 in the right leg. Brain MRI and MRA did not reveal additional abnormality. Aortic angioplasty eliminated the stenosis (figure 2) and normalized the blood pressure. He developed posthemorrhagic hydrocephalus requiring shunting.

The common causes for spontaneous intracerebral hemorrhage in term neonates include coagulopathy, cerebral vascular malformation, tumor, infarction, and hypertension. ${ }^{1,2}$ Aortic coarctation, a rare but surgically amenable condition, should be considered in the differential diagnosis.

\section{REFERENCES}

1. Sandberg DI, Lamberti-Pasculli M, Drake JM, Humphreys RP, Rutka JT. Spontaneous intraparenchymal hemorrhage in fullterm neonates. Neurosurgery 2001;48:1042-1048.

2. Jordan LC, Kleinman JT, Hillis AE. Intracerebral hemorrhage volume predicts poor neurologic outcome in children. Stroke 2009;40:1666-1671.
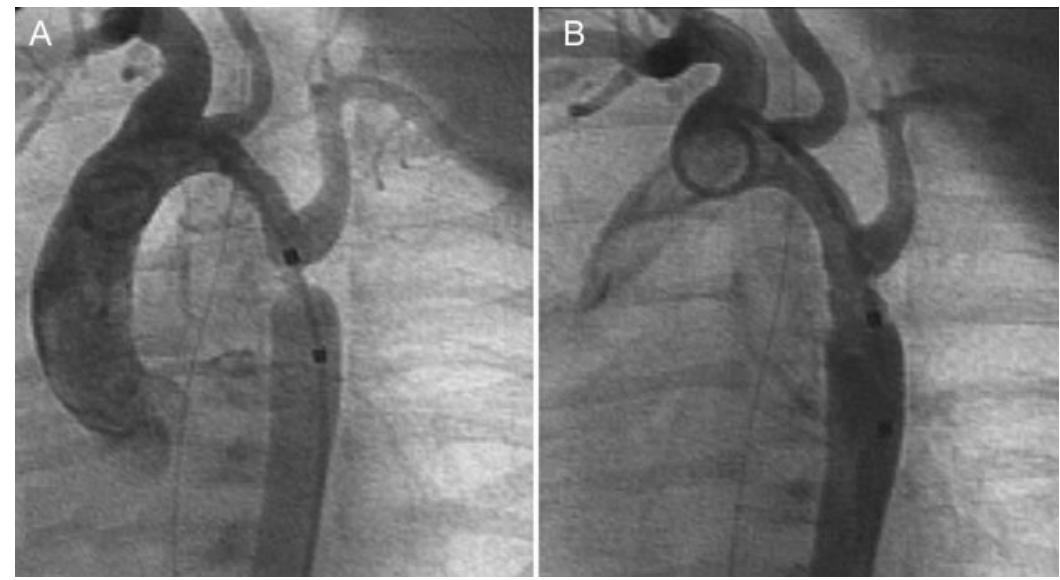

Aortogram showed focal aortic stenosis distal to the left subclavian artery orifice (A), and resolution of the coarctation after angioplasty (B).

From the Department of Neurology (X.D., C.M.I.), University of Virginia, Charlottesville; and Department of Radiology (Y.T.), Virginia Commonwealth University, Richmond.

Disclosure: The authors report no disclosures. 


\section{Neurology}

\section{Teaching NeuroImages: Neonatal intracerebral hemorrhage associated with aortic coarctation}

Xinli Du, Yang Tang and Christopher M. Inglese

Neurology 2010;74; 52

DOI 10.1212/WNL.0b013e3181d6b100

\section{This information is current as of March 29, 2010}

\section{Updated Information \&} Services

References

Subspecialty Collections

Permissions \& Licensing

Reprints including high resolution figures, can be found at: http://n.neurology.org/content/74/13/e52.full

This article cites 2 articles, 1 of which you can access for free at: http://n.neurology.org/content/74/13/e52.full\#ref-list-1

This article, along with others on similar topics, appears in the following collection(s):

Childhood stroke

http://n.neurology.org/cgi/collection/childhood_stroke Intracerebral hemorrhage

http://n.neurology.org/cgi/collection/intracerebral_hemorrhage

Information about reproducing this article in parts (figures,tables) or in its entirety can be found online at:

http://www.neurology.org/about/about_the_journal\#permissions

Information about ordering reprints can be found online:

http://n.neurology.org/subscribers/advertise

Neurology ${ }^{\circledR}$ is the official journal of the American Academy of Neurology. Published continuously since 1951, it is now a weekly with 48 issues per year. Copyright . All rights reserved. Print ISSN: 0028-3878. Online ISSN: 1526-632X.

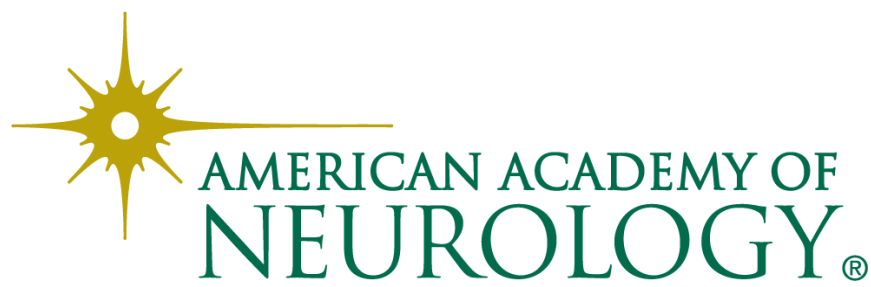

